九州大学学術情報リポジトリ

Kyushu University Institutional Repository

Preliminary investigation of the effect of the use of pineapple juice and the waste on ethanol production by Zymomonas mobilis

Hi lary, Zakpaa D.

Laboratory of Microbial Technology, Faculty of Agriculture, Kyushu University

Tanaka, Kenj i

Laboratory of Microbial Technology, Faculty of Agriculture, Kyushu University

Ishizaki, Ayaaki

Laboratory of Microbial Technology, Faculty of Agriculture, Kyushu University

https://doi.org/10.5109/24290

出版情報：九州大学大学院農学研究院紀要. 43 (3/4)，pp.433-439，1999-02. Kyushu University バージョン：

権利関係 : 
J. Fac. Agr, Kyushu Univ., 43 (3·4), 433-439 (1999)

\title{
Preliminary investigation of the effect of the use of pineapple juice and the waste on ethanol production by Zymomonas mobilis
}

\author{
Zakpaa D. Hilary, Kenji Tanaka and Ayaaki Ishizaki \\ Laboratory of Microbial Technology, Faculty of Agriculture, \\ Kyushu University, Fukuoka, 812-8581 Japan \\ (Received October 27, 1998 and accepted November 6, 1998)
}

\begin{abstract}
The effect of the use of the juice of rotten-or discharged pineapple fruits and the wastes derived from the processing of pineapple juice on ethanol production by $Z$. mobilis was investigated. 2 . mobilis ATCC 10988 produced $59.0 \mathrm{gl}^{-1}$ of ethanol in the undiluted pincapple juice although the supplementation of any nutritions and the controlling of $\mathrm{pH}$ werc not carried out. Inhydrolyzed waste and the enzymatically hydrolyzed waste were also converted to ethanol at the relatively high yield coefficients. These results suggest that pinearple juice and the waste can be useful for ethanol production by 7 . mobilis. Further, it was shown that the use of expensive organic-nitrogen complex such as yeast extract and the controlling of $\mathrm{pH}$ can be omitted from the fermentation process using pineapple juice and the waste.
\end{abstract}

\section{INTRODUCTION}

The crop of pineapple fruit (Ananas comosus) is increasing in tropical regions of the world and 12,769,960 tons of pineapple were produced over the world in 1997. Most of pineapple fruits are consumed as fresh product or processed fruit (mainly canned) but very high quality fruits are only selected for the processing and shipments. Low quality fruits is therefore left to rot on the farms due to the lack of markets. A large proportion of pineapple fruits are processed into juice, leaving a large amount of unusable pulp as waste material. This pulpy waste still contains $10 \%(\mathrm{w} / \mathrm{w})$ of sugars (mainly sucrose), in addition starch and hemicellulose. On the other hand, pineapple juice contains a lots of organic nitrogen compounds and minerals. Then, it is expected that the juice from these discarded fruit as well as the waste can be useful as the low cost substrates for the fermentative production of biofuel ethanol.

The aim of this study is to investigate the effect of the use of feasibility of the juice from discharged pineapple fruit and the waste on the cthanol fermentation by $Z$. mobilis ATCC 10988.

\section{MA'lERIALS AND METHODS}

\section{Microorganism}

Z. mobilis ATCC 10988, was used throughout this study.

\section{Sample preparation}

Pineapples were purchased from a supermarket and left to fully ripen at room 
temperature for 10 days. The pineapples were peeled, and blended in a house-hold juice maker for 3 min. The juice was then extracted by squeezing through a double-fold of gauze cotton cloth, and particulate matters were removed by centrifuging at $10,000 \times g$ for $10 \mathrm{~min}$ at $4{ }^{\circ} \mathrm{C}$. The undiluted juice, containing approximately $125.0 \mathrm{~g} t^{-1}$ sucrose and the waste material obtained by the extraction of juice were separately stored at $20^{\circ} \mathrm{C}$.

\section{Enzymatic hydrolysis of pineapple waste}

Meicelase, a commercial cellulase provided by Meiji Seika Co. Ltd. (Tokyo), was used for the enzymatic hydrolysis of the pineapple wastes. A $60 \%(\mathrm{v} / \mathrm{v})$ suspension of pineapple waste was first prepared and the $\mathrm{pH}$ was adjusted to 4.8 with $5.0 \mathrm{M} \mathrm{NaOH}$. Enzymatic hydrolysis of the waste was carried out at $50^{\circ} \mathrm{C}$ and for 24 hours. The enzyme was used at a protein concentration of $0.3 \mathrm{mg} / \mathrm{ml}$ with a specific activity of 1.82 (units $/ \mathrm{mg}$ ) in filter paper assay. The reaction was terminated by heating for $10 \mathrm{~min}$ in boiling water.

\section{Preparation of culture media}

When unhydrolyzed pineapple waste was used as the substrate for ethanol fermentation by $Z$. mobilis, the waste was appropriately diluted witl distilled water before use. $\mathrm{pH}$ was adjusted to 5.5 with $5.0 \mathrm{M} \mathrm{NaOH}$ then the diluted waste was autoclaved at $121^{\circ} \mathrm{C}$ for $20 \mathrm{~min}$. When enzymatically hydrolyzed waste was used as substrate, the hydrolyzate was diluted with distilled water to give $40 \%, 30 \%$ and $15 \%$ $(\mathrm{v} / \mathrm{v})$ aliquots. Two hundred milliliter of each diluted hydrolyzate were transferred into $300 \mathrm{ml}$ flasks with cotton-stoppers. Three sets of flasks were prepared for each solution. The first set of flasks were not supplemented with any organic nutrients or mineral salts. The second set of flasks were supplemented with $5.0 \mathrm{~g} l$ ' yeast extract. The third set of flasks were supplemented with $0.5 \mathrm{~g} l^{\prime} \mathrm{MgSO}_{4} 7 \mathrm{H}_{2} \mathrm{O}$. Control cultures were also carried out by using a natural culture media containing sucrose as carbon source or glucose. The natural medium was composed of $10 \mathrm{~g} l^{-1}$ yeast extract; $1 \mathrm{~g} l^{-1} \mathrm{KH}_{2} \mathrm{PO}_{4} ; 1 \mathrm{~g} l^{-1}\left(\mathrm{NH}_{4}\right)_{2} \mathrm{SO}_{4}$ and $0.5 \mathrm{gl}^{-1} \mathrm{MgSO}_{4} 7 \mathrm{H}_{2} \mathrm{O}$, and was autoclaved at $121^{\circ} \mathrm{C}$ for $20 \mathrm{~min}$ before use. The pHs of all culture media were adjusted to 5.5 with $5 \mathrm{M} \mathrm{NaOH}$, then they were autoclaved at $121^{\circ} \mathrm{C}$ for $20 \mathrm{~min}$.

\section{Culture conditions}

Z. mobilis was refreshed by inoculating $0.5 \mathrm{ml}$ of the stock culture to $10 \mathrm{ml}$ of $\mathrm{YM}$ liquid medium (Difco) in a test tube then incubating at $30^{\circ} \mathrm{C}$ for $18 \mathrm{~h}$ without shakiry. Ten milliliter of the broth was transferred to $40 \mathrm{ml}$ of YM medium and incubated for $18 \mathrm{~h}$ at $30^{\circ} \mathrm{C}$. Cells were harvested by centrifugation at $10,000 \times g$ for $10 \mathrm{~min}$ at $4^{\circ} \mathrm{C}$, then rinsed with $50 \mathrm{ml}$ of autoclaved distilled water and centrifuged again. The cells were suspended in $50 \mathrm{ml}$ of sterilized distilled water and used for flask culture and batch culture. Batch culture was carried out using a glass jar fermenter with a total volume of 1l. The working volume was $500 \mathrm{ml}$ and the agitation speed was $200 \mathrm{rpm}$. The temperature was kept at $30^{\circ} \mathrm{C}$. In some cases, $\mathrm{pH}$ was automatically maintained at 5.5 by the addition of $2.0 \mathrm{M} \mathrm{NaOH}$ with a pH controller (PHC-2201, Biott Co., Ltd., Tokyo, Japan). Investigations using pineapple waste were carried out using $300 \mathrm{ml}$ conical flasks with cotton stopper at $30^{\circ} \mathrm{C}$ for $24 \mathrm{~h}$. 


\section{Analytical methods}

Ethanol concentration was determined by gas chromatography (GC 8 APE; Shimadzu Co. Ltd., Kyoto, Japan) equipped with a PEG column ( $80 / 100$ mesh). The temperatures in the column oven and the injection room were set to $70^{\circ} \mathrm{C}$ and $90^{\circ} \mathrm{C}$, respectively. Glucose concentration was determined by a glucose analyzer (Model 23 A, Yellow Spring Instrument Co. Ltd., Ohio, USA). Sucrose concentration was determined by using $\beta$ -fructosidase (Boehringer Mannheim, Germany). Supernatant of culture broth was diluted with $2.0 \mathrm{M}$ acetate buffer $(\mathrm{pH} 4.6)$ including the enzyme then the solution was incubated at $56^{\circ} \mathrm{C}$ for $90 \mathrm{~min}$. Concentration of liberated glucose was determined by the glucose analyzer.

\section{RESULTS}

\section{Ethanol production with undiluted pineapple juice}

Ethanol production by $Z$. mobilis ATCC 10988 using undiluted pineapple juice was first investigated by batch culture. The control culture was also carried out using the natural culture medium containing $110 \mathrm{~g} l^{-1}$ sucrose. The controlling of $\mathrm{pH}$ during cultivation was not carried out. Figure 1 shows the time courses of ethanol production. The final concentration of ethanol was $59.0 \mathrm{~g} l^{-1}$ while that in the culture with $110 \mathrm{~g} l^{-1}$ sucrose medium was $36.9 \mathrm{~g} l$. Figure 2 shows the change in residual concentrations of

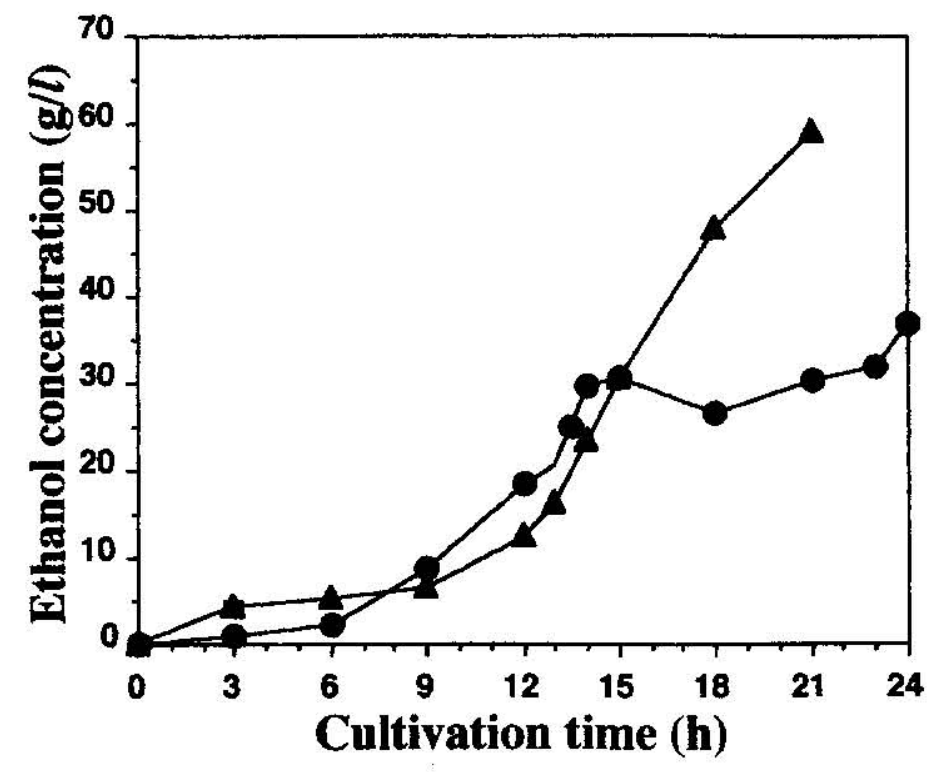

Fig. 1. Time course of ethanol production in batch cultures of $Z$. mobitis ATCC 10988 using undiluted pirteapple juice and natural culture medium without controlling $\mathrm{pH}$. Symbols: undiluted pineapple juice; ( $\boldsymbol{\Delta}$ ), natural medium containing $110 \mathrm{gl}$ l'sucrose; 


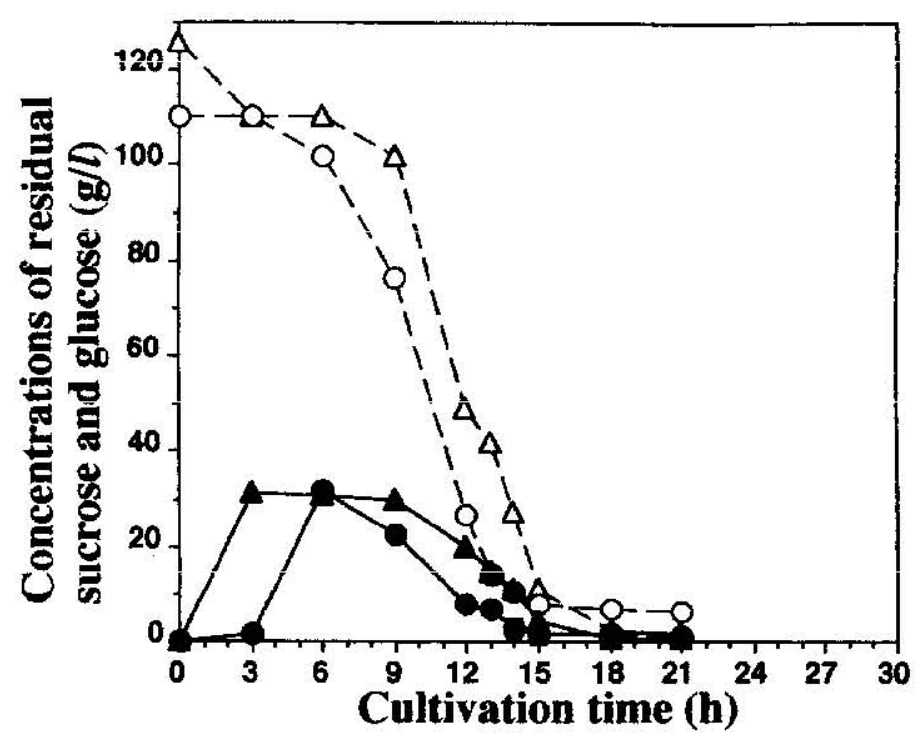

Fig. 2. The changes in residual sugar concentration in batch cultures of 7. mobilis ATCC 10988 using undiluted pineapple juice and natural culture medium without controlling $\mathrm{pH}$. Symbols: undiluted pineapple juice; ( $\boldsymbol{A})$, natural medium containing $110 \mathrm{~g} l$ ' sucrose; (P). Solid lines indicate glucose concentration and broken lines indicate sucrose concentration.

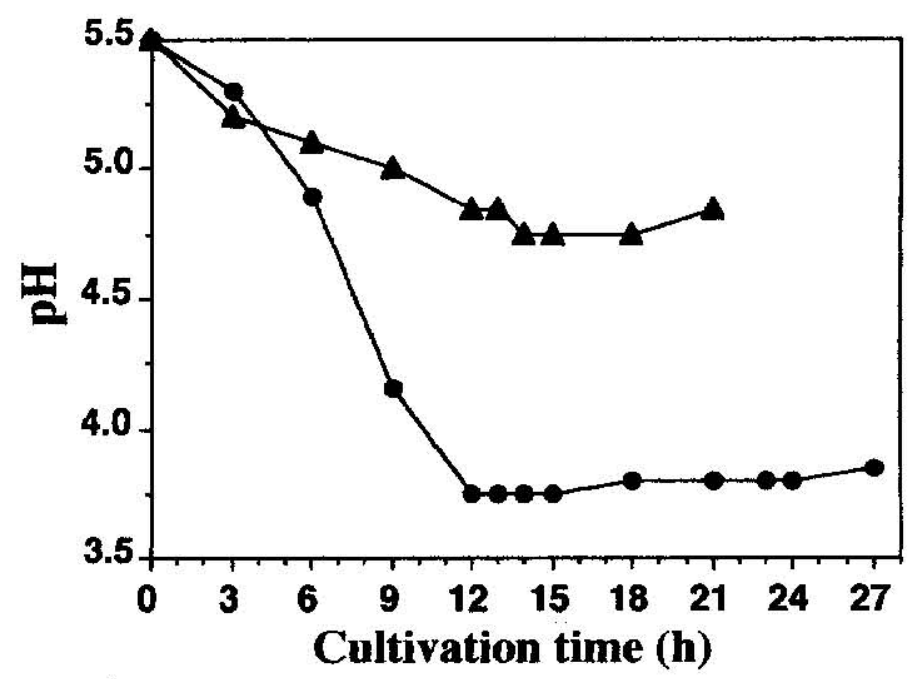

Fig. 3. The changes in $\mathrm{pH}$ in batch cultures of $Z$. mobilis ATCC 10988 using undiluted pineapple juice and natural culture medium without controlling $\mathrm{pH}$. Symbols: 11ndiluted pineapple juice; (A), natural medium containing $110 \mathrm{~g} l^{-4}$ sucrose; (O). 
Table 1. The results of ethanol fermentation by $Z$. mobilis ATCC 10988 using pineapple juices supplemented with $5.0 \mathrm{~g} / l$ yeast extract or $0.5 \mathrm{~g} / \mathrm{MgSO}{ }_{4} 7 \mathrm{H}_{2} \mathrm{O}$

\begin{tabular}{ccc}
\hline $\begin{array}{c}\text { Nutrients } \\
\text { supplemented } \\
\text { to prineapple juice }\end{array}$ & $\begin{array}{c}\text { Fermentation time } \\
\text { (h) }\end{array}$ & $\begin{array}{c}\text { Ethanol yield referred } \\
\text { to theoretical yield } \\
(\%)\end{array}$ \\
\hline $5.0 \mathrm{~g} / \mathrm{l}$ yeast extract & 21 & 97.7 \\
$5.0 \mathrm{~g} / \mathrm{MgSO} .7 \mathrm{H}_{2} \mathrm{O}$ & 21 & 78.3 \\
\hline
\end{tabular}

glucose and/or sucrose in each cultivation. Sucrose was hydrolyzed to glucose and fructose then utilized by $Z$. mobilis ATCC 10988. The yield of ethanol in the batch culture with pineapple juice was $92.4 \%$ of theoretical yield while that with $110 \mathrm{~g} l^{-1}$ sucrose medium was only $65.6 \%$. These fermentation results suggest that pineapple juice contains adequate amounts of organic nitrogen compounds which are essential for the sufficient cell growth of $Z$. mobilis. Filtered pineapple juice contains $17.1 \mathrm{gl}$ ' protein; $3.3 \mathrm{~g} l^{-1}$ total sugars; $2.6 \mathrm{~g} l^{+}$citric acid; $0.7 \mathrm{~g} l^{-1}$ ascorbic acid; and $0.6 \mathrm{~g} l^{-1}$ phenolics (Lozano-de-Gonzalez et al., 1993). Therefore, it was expected that the juice extracted from rotten or discarded pineapples can be fermented by $Z$. mobilis without supplementing with yeast extract. Figure 3 shows the change in $\mathrm{pH}$ during batch culture. In the batch culture using the natural medium with $110 \mathrm{gl}$ sucrose, $\mathrm{pH}$ decreased to 3.8 after $12 \mathrm{~h}$ of cultivation. In the culture using pineapple juice, the decrease in $\mathrm{pH}$ was very slow and $\mathrm{pH}$ was always higher than 4.8 until the fermentation finished. It was thought that pineapple juice has strong buffering action against $\mathrm{pH}$ change, which resulted in the reduction in fermentation time in the culture with pineapple juice than in the culture with sucrose medium. The effect of the addition of $5.0 \mathrm{~g} l^{-1}$ yeast extract or $0.5 \mathrm{~g} l^{-1} \mathrm{MgSO}_{4} 7 \mathrm{H}_{2} \mathrm{O}$ into pineapple juice on the ethanol production by $Z$. mobilis was investigated by batch culture without controlling $\mathrm{pH}$. The fermentation results are shown in Table. 1 . The use of yeast extract slightly increased ethanol yield from pineapple juice however the use of $\mathrm{MgSO}_{4} 7 \mathrm{H}_{2} \mathrm{O}$ decreased ethanol yield.

\section{Ethanol production with pineapple waste by $\boldsymbol{Z}$. mobilis}

The bulk of the waste discharged from the pineapple juice-manufacturing process is pulp of the fruit. This bulky waste is rich in fiber, carbohydrates and unextracted juice. Therefore, ethanol fermentation using the pineapple waste was also investigated. Figure 4 shows the concentrations of ethanol after $24 \mathrm{~h}$ of cultivation when various dilutions of unhydrolyzed pineapple waste were used. More than $3.5 \mathrm{~g} l^{-1}$ ethanol was produced in the culture using the $15 \%(\mathrm{v} / \mathrm{v})$ dilution of unhydrolyzed waste. In the control cultures using $5 \mathrm{~g} l^{\prime}$ sucrose and $5 \mathrm{~g} l^{\prime}$ glucose media, ethanol production were $1.3 \mathrm{~g} l^{-1}$ and $2.3 \mathrm{~g} l^{-1}$, respectively. The ethanol production by $Z$. mobilis with the hydrolyzed waste was also investigated and the result is shown in Fig. 5. When the $15 \%, 30 \%$ and $40 \%(\mathrm{v} / \mathrm{v})$ dilutions of the hydrolyzed waste were used, the yields of ethanol were $5.0 \mathrm{~g} l^{-1}, 7.6 \mathrm{~g} l^{-1}$, and $9.3 \mathrm{gl}$, respectively. The addition of $5.0 \mathrm{~g} l^{-1}$ yeast extract to hydrolyzed waste didn't 


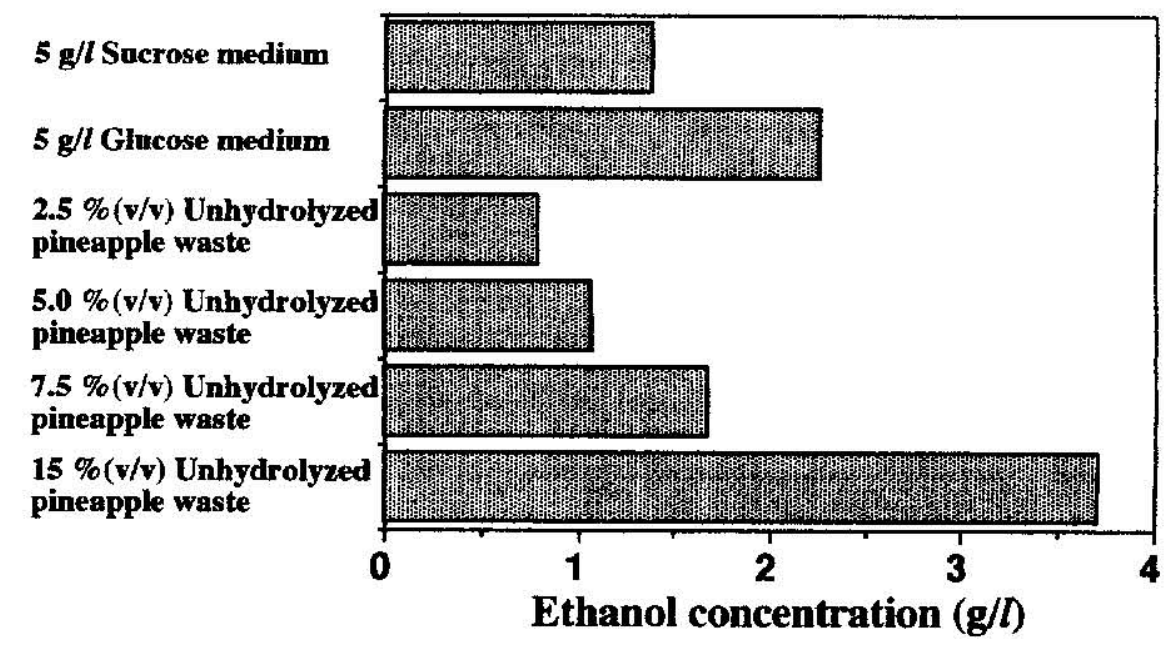

Fig. 4. Ethanol production in tlask cultures of Z. mobilis ATCC 10988 using various dilutions of unhydrolyzed pineapple waste.

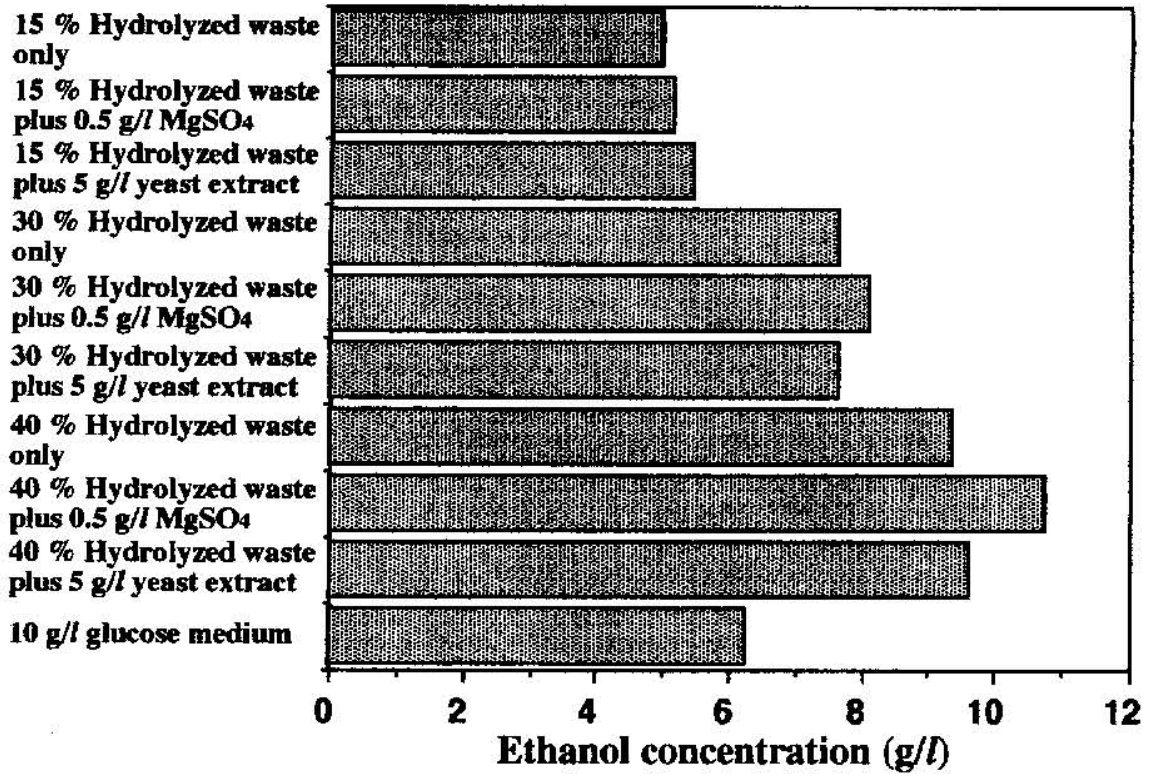

Fig. 5. Ethanol production in flask cultures of $Z$. mobilis ATCC 10988 using various dilutions of hydrolyzed pineapple waste. 
promote ethanol production by $Z$. mobilis. On the other hand, the addition of $0.5 \mathrm{~g} l$ ' $\mathrm{MgSO}_{4} 7 \mathrm{H}_{3} \mathrm{O}$ into the hydrolyzed waste solutions slightly increased ethanol production.

\section{DISCLSSION}

Alain et al. reported the ethanol production from pineapple juice by the best-preselected yeast strains (Alan, 1987). When Sarcharomyces cerevisiae var. sake was used, the maximum yicld of ethanol ( $89 \%$ of theoretical yield) was obtained but the productivity was $1.44 \mathrm{~g} l{ }^{\prime} \mathrm{h}$ '. When $S$. cerevisiae $\mathrm{CM} 1$ was used, the maximum ethanol productivity $\left(2.22 \mathrm{~g}^{-1} \mathrm{~h}\right.$ ) ) was obtained but the ethanol yield was $77 \%$. In our study employing $Z$. mobilis ATCC 10988, the ethanol yicld from pineapple juice was $92.4 \%$ of theoretical yield and the productivity was $2.68 \mathrm{~g} l^{-1} \mathrm{~h}^{\mathrm{i}}$. On the other hand, in the culture with the pineapple wastes, the yicld coefficient of ethanol was not determined completely. The pulpy waste (press cake) of the pineapple fruits consisted of about $80 \%$ $(\mathrm{w} / \mathrm{w})$ of water, $10 \%(\mathrm{w} / \mathrm{w})$ of saccharides and $10 \%(\mathrm{w} / \mathrm{w})$ of other components. Therefore, theoretical yield of ethanol from the waste was estimated to be about $0.51 \mathrm{~g}$-ethanol/g-waste. When a $60 \%(\mathrm{v} / \mathrm{v})$ suspension of pineapple waste was hydrolyzed and $30 \%(\mathrm{v} / \mathrm{v})$ dilution of the hydrolyzate was used for fermentation, $7.6 \mathrm{~g} l^{-1}$ of ethanol was produced. Then, in the casc of using $30 \%(\mathrm{v} / \mathrm{v})$ dilution of hydrolyzed waste, the yield of ethanol in the culture was estimated to be $82.6 \%$ of the theoretical yield. Further, it was shown that the pineapple juice and the waste contain a lots of organic nitrogen compounds which are essential for the growth of this microorganism, and the controlling of $\mathrm{pH}$ by the addition of alkali can be omitted. These results suggest that the juice from discharged pineapple fruits and the waste can be useful as low cost substrate for the production of biofuel ethanol by $Z$. mobilis.

The addition of magnesium sulfate into hydrolyzed waste slightly promoted ethanol production by $Z$. mobilis. It is known that magnesium ions are cofactors for a variety of enzymes of the Entner-Doudoroff pathway (Osman and Ingram, 1985). Further, magnesium ions have the ability to restore the stability of outer membrane permeability of the cell, therefore the addition of magnesium ions is useful for the restore of the ethanol-damaged $Z$. mobilis cells and for the preventing the cells from the leakage of intermediates. This is particularly important when ethanol concentration in culture system increased. However, the reason why ethanol yield decreased in the culture using pineapple juice which was supplemented with $0.5 \mathrm{gl}^{-1} \mathrm{MgSO}_{4}$ is not clear at present.

\section{REFERENCES}

Alain, K., A. N. Georges and Y. Aka 1987 Ethanol production from pineapple juice in Cote d'Ivoire with preselected yeast strains. J. Ferment. Technol., 65: 475-481

I.ozano-de-Gonzalez, P. (G., D. M. Barrett, R. E. Wrolstad and R. W. Durst 1993 Enzymatic browning inhibited in fresh and dried apple rings by pineapple juice. J. Food Sci., 58: 399-404

Osman, Y. A. and L. O. Ingram 1985 Mechanism of ethanol inhibition of fermentation in Zymomonas mobilis CP4. J. Bacteriol., 164: 173-180 